\title{
TAIDE- JA POPULAARIMUSIIKKI
}

Musica extracolta $\cdot$ vakava taide $\cdot$ uuden musiikin reseptio $\cdot$ musiikin todellinen vallankumous - totuudellisuus - valheellinen eskapismi - musiikinlajien samanarvoisuus - musiikillinen fasismi - Oramon ja Gronowin väittely $\cdot$ musiikin julkinen tuki - taide-viihde -jako - fylogeneettinen ja ontogeneettinen luomistapahtuma • stereotyyppisyys elinehtona ja kuoliniskuna

Tuskin mikään muu taide on tănăăn yhtä selvăsti jakautunut erilaisiin alakulttuureihin kuin musiikki. Năillă on kullakin oma musiikillinen kielensă ja tietoisuutensa, normistonsa ja arvomaailmansa, omat harjoittajansa ja kuulijansa, organisaationsa ja instituutionsa sekä oma yhteiskunnallis-taloudellinen asemansa ja historiansa. Vasta kaikkien näiden tekijöiden huomioon ottaminen voisi johtaa kunkin alakulttuurin määritelmään, joka kertoisi enemmän kuin tutut etiketit. Erimielisyyttă ei synnytă niinkäăn erilaisten musiikkilajien olemassaolo kuin niiden arvoväritteiset nimikkeet. Useinhan kysytăăn esim.: "Onko taidemusiikki sitten aina vakavaa, eikö viihde voi olla taidetta?" Lajinimikkeet olisikin syytä heti alkajaisiksi problematisoida (vrt. Dahlhaus 1967b, Karbusicky 1975), mutta pyrin suoremmin itse asiaan.

Selvimmin erottuvan saarekkeensa näyttăă muodostavan se, mitä on totuttu kutsumaan taidemusiikiksi. Juuri tälle alueelle on keskittynyt pisin ja jäsentynein käytännöllis-teoreettinen perinne, vakiintunein koulutus ja tutkimus sekă yhteiskunnan taloudellinen ja henkinen tuki. Näistä eduista huolimatta taidemusiikin kvantitatiivinen osuus musiikin kulutuksessa ja yleisessä musiikillisessa tietoisuudessa on minimaalinen. Taidemusiikin kentässä puolestaan văhemmistöön jää oman aikamme musiikki, josta edelleen "varsinaiset modernistiset" suuntaukset ovat vain osa.

Taidemusiikin ulkopuolelle jää laaja ja monitahoinen kimppu alakulttuureja. Niitä selvimmin yhdistävä ulkonainen piirre on juuri se, että ne jäävät taidemusiikin ja samalla järjestelmällisen koulutuksen ja yhteiskunnan tuen ulkopuolelle. Kysymyksessä on siis - italialaista termiä käyttääkseni - musica extracolta (Fabbri 1982, 133). Käytämme siitä monia eri ilmaisuja kuten "populaarimusiikki", "kevyt musiikki", "viihdemusiikki" ja "käyttömusiikki" kaikki nämä käsitteet kertovat jotain olennaista, mutta mikään niistä ei kata koko aluetta. Tästä alueesta tyydyn oheisessa karkeassa kaaviossa (kuva 1) erottamaan kaksi musiikin lajia, jazzin ja kansanmusiikin. Kumpikaan näistä ei ole koko- 


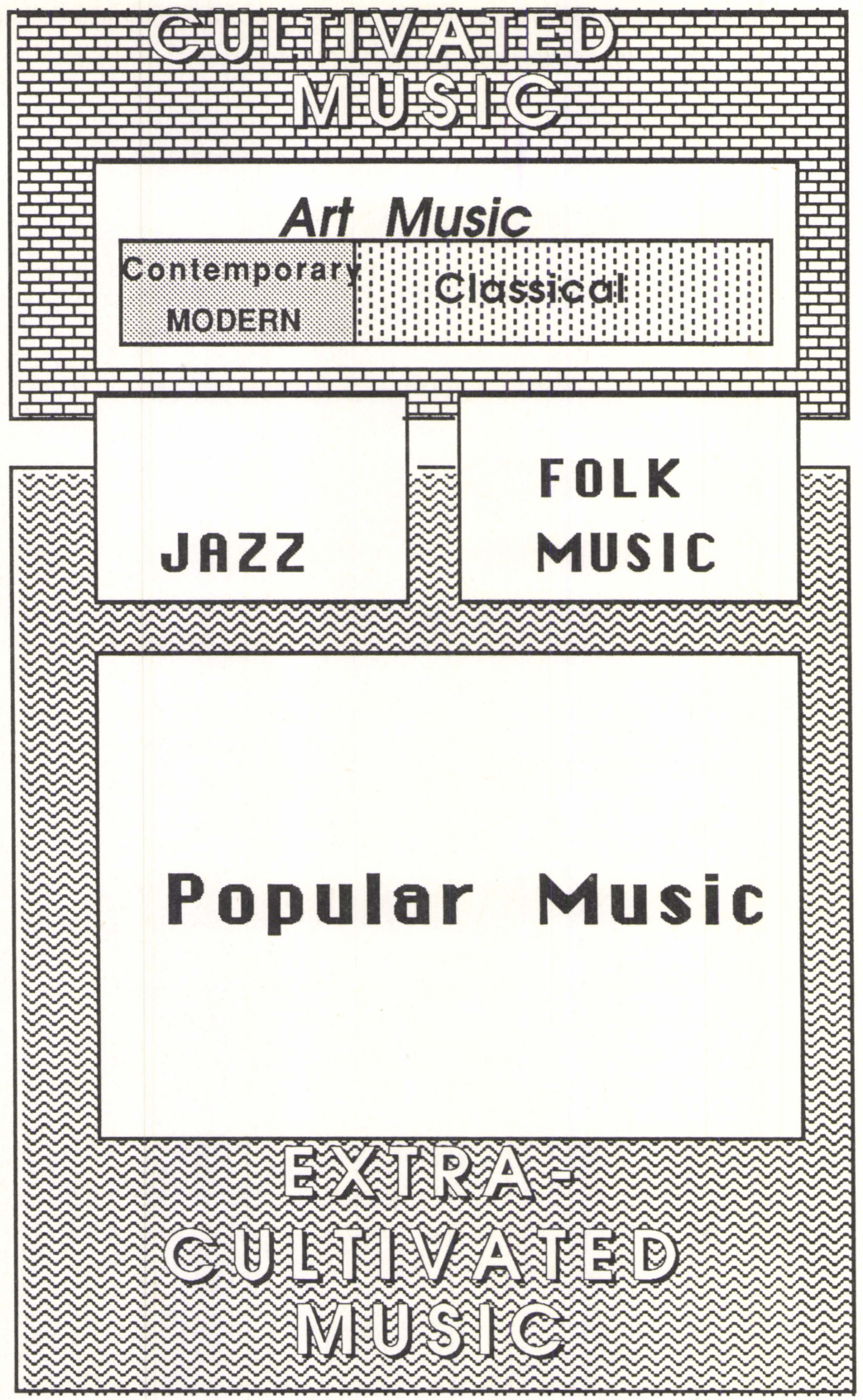

Kuva 1. Kaavio musiikinlajien välisistä suhteista. 
naan sidoksissa kaupalliseen kulttuuriteollisuuteen eikä kokonaan yhteiskunnan taloudellis-henkisen tuen ulkopuolella. Muita lajeja kutsun tăssă yksinkertaisesti populaarimusiikiksi.

\section{Historiallista taustaa}

Historiallisen taustan valaisemiseksi tuon ensiksi esiin eräită huomioita, joita saksalaiset musikologit ovat esittäneet tutkittuaan "triviaalimusiikiksi" kutsumiaan musiikin "alempia kerrostumia" (Dahlhaus 1967a). 1700-luvun jălkipuolelle asti "alempi" musiikki tuomittiin moraalisin, sosiaalisin ja sävellysteknisin perustein. Mutta kun sävellystekniikka sitten mekanisoitui, ammatilliset kriteerit menettivăt merkitystăän. Empfindsamkeit, Sturm und Drang ym. välitöntä tunnetta painottavat suuntaukset johtivat samalla sentimentalismiin. Säveltåjien päähuomio siirtyi kontrapunktista harmoniaan ja kudosrakenteesta melodiaan, jolloin musiikin alkeiden hallitseminen muuttui helpommaksi mutta todella taiteellinen säveltäminen vastaavasti vaativammaksi.

Näin kehittyi romantiikan triviaalimusiikki. Porvariston salongeissa tietynasteinen laulu- ja soittotaito olivat săädyn symboleja, ja salonkien tarpeeseen kustantajat ryhtyivăt massatuotantona tarjoamaan lauluja, romansseja, pseudovirtuoosisia pianokappaleita ym. Triviaalimusiikkia ei kuitenkaan kritisoitu sosiaalisin perustein, sillă sen yleisőpohjan muodosti sama yhteiskuntaluokka, jonka varaan rakentui myös sinfonisen musiikin konsertti-instituutio.

Romantiikan taidekăsitteen kanssa triviaalimusiikki ei ollut ristiriidassa siksi, ettă siină olisi rikottu săvellysteknisiă normeja, vaan siksi ettă se katsottiin banaaliksi ja epigonaaliseksi. Se ei täyttänyt esteettisiä kriteerejă, jotka kiteytyivät originaalisuuden kategoriaksi. Aito uusi taide oli Robert Schumannin terminologian mukaan "romanttista", ja siită poikkesivat yhtäältä konservatiivit, joita hän kutsui "klassikoiksi" tai "reaktionääreiksi", toisaalta päivăkohtaisen muodin seuraajat, joita hän kutsui "moderneiksi". Sanalla "moderni" oli siis eri merkitys kuin nykyisin, mutta kannattaa panna merkille, että nykyinen asetelma alkoi jo tuolloin hahmottua. Säveltäjät jaettiin kolmeen ryhmään: taidemusiikin perinteen uudistajiin ja säilyttajjiin ja ajanvietemuusikoihin. Juuri uudistajat korostivat yksilöllistä persoonatyyliă, mikä johti lajiperinteen ja musiikillisen yleiskielen hajaantumiseen.

1800-luvun alussa konserttiohjelmat koostuivat vielä puhtaasti oman ajan musiikista, ja säveltäjät osallistuivat teostensa esityksiin. Mutta musiikkikoulutuksen ja -tutkimuksen sekä konsertti-instituution kehittyessä esittävästä ja luovasta muusikosta tuli kummastakin vähitellen oman alansa ekspertti. Ensinnäkin esittäjien päämielenkiinto suuntautui yhä enemmän historialliseen musiikkiin, toiseksi virtuoosi- ja kapellimestarikultti kohdistivat kuulijan huomion pikemmin tulkintoihin kuin itse teoksiin. Seuraukset voi jokainen nyt havaita tarkastelemalla konserttien ja levykauppojen repertuaaria: samat klassiset ja romanttiset standarditeokset ovat tarjolla yhä uudelleen satoina uusina interpretaatioina. Väittäisinkin, että nykymusiikkiteoksen vastaanotto on peri- 
aatteellisesti erilainen kuin standarditeoksen, mikă ei siis johdu pelkästään sen uutuudesta.

Omaa aikaamme lähestyttăessä modernin taidemusiikin säveltäjä on joutunut yhä enemmän eristyksiin. Hän on (uusklassisia ja käyttömusiikillisia virtauksia lukuun ottamatta) pitäytynyt romanttisessa roolissaan ihmiskunnan tiennäyttäjänä, profeetallisena totuuden etsijänä, joka kieltäytyy helpon suosion tavoittelusta. Varhaisklassismin käytännöllinen, arkitodellisuuden funktioihin sitoutuva asenne on jäänyt kauas taakse - käsityőläisyys on potensoitunut konstruktivismiksi ja rationalismiksi - ja usko "taiteeseen taiteen vuoksi" on lujittunut. Tämä ei suinkaan ole merkinnyt laajamittaista formalismia, kuten modernismia ja progressiivista kehitystä kritisoivat tahot ovat väittäneet. Tuskin kuulijoitakaan on vieraannuttanut musiikillisen ilmaisun tai sanoman puute vaan ilmaisukeinojen kompleksisuus ja nopea uudistuminen.

Viimeistä pisaraa näyttää merkinneen atonaalisuus. Vastustajiensa mielestä se on riistänyt kuulijoilta keskeisimmän, suorastaan "luonnolliseksi" ja näin muodoin epähistorialliseksi julistetun tavan hahmottaa musiikkia. Sen jälkeen kun modernismi huipentui 1950-luvun serialismiin ja hajaantui tyylipluralismiksi, on käynyt perin vaikeaksi paikantaa "todellista" avantgardea. Uudistuspyrkimysten ohella esiintyy vankkaa traditionalismia ja postmodernismia; edellinen on restauroinut tonaalisuuden, jälkimmäinen taas palaa siihen sitaatti- ja alluusiotekniikassaan. Monessa mielessä tonaalisuudelle tarjoaa varsin osuvan rinnakkaisilmiön visuaalisten taiteiden figuratiivisuus.

On kuitenkin esitetty, että vuosisatamme musiikin todellista vallankumousta ei pitäisikään etsiä Debussyn, Stravinskyn tai Schönbergin teoksista vaan afroamerikkalaisen populaarimusiikin esiinmarssista (Pleasants 1969). Tämän edellytyksinä ovat olleet $\mathrm{mm}$. teollisen yhteiskunnan uusi sosiaalinen rakenne, yhä useampien ihmisten mahdollisuus käyttää yhä enemmän rahaa ja aikaa musiikin kulutukseen sekä erityisesti uudet elektroniset mediat, jotka ovat ensinnäkin mahdollistaneet myös kirjoittamattomien musiikkilajien tallentamisen ja laajamittaisen levittämisen ja toiseksi luoneet musiikille kokonaan uusia funktioita (Tagg 1982, 39). Äänilevyteollisuus rakentui nykyisen kaltaiseksi jo ennen 1. maailmansotaa, mutta sen varsinainen ekspansio alkoi 20-luvulla ja jatkui sitten 60-luvulla sen selvittyä aänielokuvan ja radion aiheuttamasta takaiskusta. Nykyisin radioyhtiöt ovat ohjelma-aikaansa täyttäessään suurelta osalta riippuvaisia kaupallisten levy-yhtiöiden massatuotannosta, ja yleisessä tietoisuudessa äänilevy ja musiikki alkavat todellakin olla synonyymeja. (Gronow 1983, 72).

1800-luvun salonkimusiikin ja kansanomaisten musiikkilajien väistyminen teollisen populaarikulttuurin tieltä on liian monipolvinen (ja myös tutkimaton) prosessi tarkasteltavaksi lähemmin tässä yhteydessä, mutta huomattakoon, että se tapahtui rinnan modernin taidemusiikin isolaation kanssa. Niinpä populaarimusiikin suosion syitä on etsitty vertaamalla sitä 1700-luvun sävellyskäytäntöön: säveltäjät ovat vain käytännön muusikkoja, jotka originaalisuuteen pyrkimättä puhuvat aikansa yleiskieltä ja luovat ohjelmistoa päivän tarpeeseen kuulijoidensa toiveita seuraten (Pleasants 1955, 86-87). Sanomattakin on selvää, että populaarimusiikki kaikista uusista piirteistään huolimatta pitäytyy 
tiukasti siihen funktionaaliseen tonaalisuuteen, jonka taidemusiikki loi satoja vuosia aiemmin.

\section{Näkemyseroja}

Taidemusiikin puolustajat korostavat musiikin kognitiivista, esteettistä ja kasvatuksellista tehtäväă, musiikkia keinona ymmärtäă todellisuuden syvintä olemusta tavalla jota mikään muu kulttuuri-ilmiö ei voi korvata. Tämä tehtävä on tiukasti sidoksissa musiikin arvoon. Merkittävä musiikki on vastaanotettava esteettisessä kontemplaatiossa, joten se ei saa olla liiaksi sidoksissa ulkomusiikillisiin funktioihin. Nykysäveltäjät seuraavat usein Arnold Schönbergin ja Theodor W. Adornon Wahrhaftigkeit-filosofiaa, jonka mukaan sävellyksen ei pidä ensisijaisesti olla kaunis vaan "totuudellinen", ts. sen pitää kriittisesti heijastaa syntyajankohtansa todellisuutta, muussa tapauksessa se on valheellista eskapismia (Heiniö 1984, 294-304). Huomattakoon, ettă tällä ajatuksella ei ole vastustettu ainoastaan populaarimusiikkia vaan myös konservatiivista taidemusiikkia (Adorno 1972). Musiikin triviaalisuutta ei siis määritellä vain esteettis-sävellysteknisesti vaan myös moraalisesti (Dahlhaus 1967b, 4). Nämä lähtökohdat saavat populaarimusiikin näyttämään kertakäyttötavaralta, joka on liian pinnallista ja helppotajuista tuottaakseen syvempää tyydytystä.

60-luvun Suomessa populaarimusiikin kannattajien kanta tiivistyi iskulauseeseen "Hyvä iskelmä on parempi kuin huono sinfonia". Tätä väitettä Joonas Kokkonen piti "yhtä älykkäänä" kuin lausahdusta "Hyvä lattia on parempi kuin hyvä katto". Taidemusiikin taholta tähdennettiin siis lähinnä musiikinlajien vertailukelvottomuutta; iskelmien tarpeellisuus kyllä myönnettiin ja jazzia jopa arvostettiinkin. (ks. Kokkonen 1983). Eriytyneempiä mutta samalla varauksellisia kantoja kuultiin vasta 70-luvulla, jolloin esim. Erkki Salmenhaara kirjoitti:

Taiteen ja viihteen olemusero muodostuu jo niiden syntyhetkellä, sillä se missä tarkoituksessa teos on tehty, painaa leimansa itse teokseen. Taideteos tehdään sen itsensä vuoksi: jotta se olisi kaunis, ehjä ja juhlallinen, jotta se välittäisi tietoa ja kokemuksia, joilla on ollut syvää merkitystä tekijälle. Viihdetuote tehdään vastaamaan kysyntää, ja se on hyvä ja arvokas, jos se menee kaupaksi. Markkinat ovat kuitekin oikulliset, ja siksi on varminta tuottaa itse kysyntäkin. Taide on ihmisen puhetta toiselle: Viihde on tuottajan puhetta kuluttajalle. Taide ei kulu. (Salmenhaara 1976, 153).

Tässä kaikuvat Adornon musiikkisosiologian (Adorno 1962) pääteesit, joiden mukaan "kuuntelun regressio" tulee esiin passiivisessa, väärän tietoisuuden hallitsemassa kuulijatyypissä, "viihdekuulijassa". Tämän harrastamalla musiikilla on fetissin ja kauppatavaran luonne ja sen arvo on vaihtoarvoa. Adorno jaottelee musiikin edelleen yhtäältä kriittiseen ja ei-standardisoituun, toisaalta epäkriittiseen ja standardisoituun. Ei liene epäilystä siitä, kummalle puolelle hän sijoittaa avantgardistisen taidemusiikin, kummalle populaarimusiikin. 
Esimerkin suomalaisen taidemusiikkitutkijan näkemyksistă tarjoaa Ilkka Oramo. Hăn arvostelee ankarasti "sosiologista musiikinteoriaa", joka pyrkii arvioimaan kaikkea musiikkia funktionaalisesti ja palauttamaan taiteellisen arvon relatiivisiin, kunkin sosiaalisen ryhmän sisällă päteviin arvostuksiin. Oramon mukaan

ajatus musiikista tiedostamisen ja kommunikaation lajina romuttaa ne perusteet, joihin nojautuu väite taiteen ja viihteen, sinfonian ja iskelmän samanarvoisuudesta. Ne voivat olla samanarvoisia (tai eriarvoisia) jossakin väline- tai vaihtoarvojen järjestelmässä, mutta tällä ei ole mitään relevanssia taiteen 'olemuksen' kannalta. --- Taiteellisen arvon kannalta musiikilliset teokset ovat väistämättä eriarvoisia, ja tämä arvo määräytyy niiden edustamasta tiedostamisen asteesta, eräässä mielessä niiden 'totuudesta'. (Oramo 1974, 334).

Oramon kritiikki kohdistui populaarimusiikin kannattajien ajatukseen, jonka mukaan kaikki musiikkilajit ovat periaatteessa samanarvoisia ja näin muodoin yhteiskunnan yhtäläisen tuen arvoisia. Esim. sosiologi Pekka Gronowin mukaan sävelteokset ovat esineită, joihin ei sellaisenaan sisălly mitäăn niiden omasta luonteesta johtuvia arvoja, vaan arvot ovat peräisin ihmiseltä, ne ovat mielivaltaisesti syntyneită sosiaalisia järjestelmiă (Gronow 1965; 1971). Tămän ajattelun pontimena on etnomusikologia, joka ei halua tarkastella musiikkia autonomisena ilmiőnä vaan sosiaalis-kulttuuristen tekijőiden kentässä. Tyypillinen on esim. John Blackingin näkemys:

Art does not consist of products, but of the processes by which people make sense of certain kinds of activity and experience. Music is available-for-use ... and musical values resides not in any piece or style of music, but in the ways that people address themselves to listening and performance. (Blacking 1981, 12).

Blackingin mielestä populaarimusiikin esittäminen ja kuunteleminen eivät aseta sen vähäisempiä vaatimuksia kuin taidemusiikinkaan. Hän ei myöskään katso sellaisten termien kuin "folk", "art" ja "popular" kertovan mitään olennaista musiikin tyyleistä, sillä niitä voidaan soveltaa mihin musiikin lajiin tahansa. Marx haaveili yhteiskunnasta, jossa taiteilija kategoriana kävisi tarpeettomaksi; Blacking puolestaan yhteiskunnasta, jossa musiikkityylejä jaottelevia kategorioita ei enää tarvittaisi (Blacking 1981, 14).

Joidenkin etnomusikologien mielestä musiikkia ei voi edes jaotella sen omien ominaisuuksien perusteella vaan sen mukaan, miten se toimii kauppatavarana: subventoitu ja subventoimaton musiikki (Brooks 1982, 11). Arvottava jaottelu on tuomittu myös siksi, että sitä ei tunneta länsimaiden ulkopuolella; kehitysmaiden kannalta sitä on pidetty jopa "kulttuurikolonialismina" (Lipponen ibid., 17) tai "musiikillisena fasismina" (Saunio 1982, 7). Eniten populaarikulttuurin kannattajia on siis kiusannut taide-viihde -dikotomian yksioikoisuus, joka unohtaa erilaiset välimuodot ja antaa ymmärtää, ettă populaarimusiikki kokonaisuudessaan olisi osa tajuntateollisuutta, "ihmistä vastaan suunnattu salaliitto" (Lipponen 1983, 30). 
Olisi tietenkin kiinnostavaa ja välttämätöntă tutkia myös musiikkipiirien ulkopuolisia näkemyksiă. Taidesäveltäjiă askarruttaa esim. se, miksi kirjallisuuden, teatterin ja elokuvan alalla tyőskentelevăt taiteilijat ja kriitikot hyväksyvät sellaisen musiikillisen ilmaisun, joka taidesäveltăjien mielestä on verrattavissa kioskikirjallisuuteen, puskateatteriin ja sarjafilmeihin, ts. miksi heidän muutoin niin hyvä makunsa pettää juuri musiikin kohdalla.

\section{Yhteiskunnallis-taloudellisia eroja}

Taiteen ja viihteen kahtiajako ilmenee ainakin Suomessa selvästi myös musiikin julkisessa tuessa, josta lähes sata prosenttia tulee kunnilta, valtiolta ja Yleisradiolta. Merja Hurrin tutkimusten (1983) mukaan n. 230 miljoonan markan tuki kohdistui vuonna 1981 seuraavasti:

\begin{tabular}{lr} 
Musiikkiopistot & $45.5 \%$ \\
Orkesteritoiminta & $32.1 \%$ \\
Ooppera & $15.9 \%$ \\
Musiikkijärjestöt, -yhteisöt, harrastajat & $1.8 \%$ \\
Taiteilijapalkat, apurahat, palkinnot ym. & $1.6 \%$ \\
Muut & $\underline{3.1 \%}$ \\
\hline & $100.0 \%$
\end{tabular}

Suomen lukuisista peruskoulutusta antavista musiikkiopistoista vain yksi on keskittynyt populaarimusiikkiin. Ainoassa musiikkikorkeakoulussamme kansanmusiikin ja jazzin opetus aloitettiin ilmeisen vaatimattomissa mitoissa 1970luvulla. Orkesteritoiminnan tukemisessa pääpaino on selvästi sinfoniaorkestereissa. Taiteilija-apurahojen alkuperäinen tarkoitus oli tukea nimenomaan kaupallisesti kannattamaonta taidemusiikkia, mutta 60-luvulta alkaen myös jazz ja kansanmusiikki ovat päässeet jossain määrin osallisiksi niistä. Erään tutkimuksen mukaan (ks. Lipponen ibid., 42) taidemuusikot nauttivat lähinnä kuukausipalkkaa, populaarimuusikot taas keikkapalkkaa; edelliset kuuluvat vuosiansioiltaan ylipäänsä taiteilijoiden kärkipäähän, jälkimmäiset matalapalkkaja vajaatyöllisyysryhmään.

On laskettu, että Yleisradio soittaa vuosittain 4000 tuntia vakavaa ja 6000 tuntia kevyttä musiikkia, mutta edellistä kuuntelee vain $7 \%$ ja jälkimmäistä 93 $\%$ kuulijoista. Vakavasta musiikista radio tuottaa itse $35 \%$ ja kevyestä alle 10 $\%$, loput tulevat äänilevyiltä (ibid., 48). Kun edelleen otetaan huomion, että Suomessa $85 \%$ (USA:ssa $97 \%$ ) myydyistä äänilevyistä on kevyttä musiikkia (ibid., 22), käy ilmeiseksi, miten ratkaiseva väline äänilevy kevyelle musiikille on. Taidemusiikin keskeisin foorumi taas on edelleen konsertti. Äänite- ja nuottituotanto, jota $e i$ ole tuettu kuin nimeksi julkisin varoin, onkin sen pahin pullonkaula.

Minulla ei tässä ole mahdollisuutta tarkistaa lainaamieni lukujen paikkansapitävyyttä - mutta ei liioin mitään erityistä syytä sitä epäilläkään. Kaiken kaikkiaan näyttää siltä, että Suomessa päätöksentekijät uskovat yhtälälä, että 
taidemusiikki on avainasemassa pyrittảessă vaalimaan ja kehittämăăn kulttuuriperintőă sekä kasvattamaan kansalaisia, ja toisaalta, ettă liiketoimintaan kytkeytynyt populaarimusiikki tulee toimeen omillaan. Tătă kantaa voitaneen puolustaa sillä, ettă nyky-yhteiskunnassamme on vaikea enäă osoittaa muita kuin historiallisia syită sille, ettei kaikilla kansankerroksilla olisi yhtäläiset mahdollisuudet nauttia taidemusiikista.

Meikäläisten etnomusikologien silmätikkuna on ollut kahtiajaon ilmeneminen radiossa ja lehdistössä. Yleisradion organisaatiossa Radio 1:n piiriin kuuluu taidemusiikkiin keskittyvä varsinainen musiikkiosasto, kun taas Radio 2:n viihdeosasto vastaa populaarimusiikista. Vastaavasti sanomalehtien konserttiarvostelut jakaantuvat kahteen sektoriin, joiden otsikkoina ovat musiikki ja jazz-pop. Etnomusikologit lienevät oikeassa siinä, ettă tässä piilee enemmänkin kuin tyhjăă nominalismia. (Vastaavanlaista asenteellisuutta voisi năhdă siină tavassa, jolla radio-ohjelmien otsakkeet jaottelevat taidemusiikkia. Vanha musiikki edustaa barokkia edeltănyttă aikaa ja uusi musiikki viime vuosikymmeniă. Mutta klassis-romanttisen kauden teokset eivăt tăllaista määrittelyă năytă kaipaavan - ne ovat siis sită varsinaista, "ajatonta" musiikkia, johon musiikillinen tietoisuus nojaa.)

Musiikkiorganisaatioiden kahtiajako ilmenee selvimmin săveltäjäyhdistyksissä. Viihdesäveltåjien, -sanoittajien ja -sovittajien yhdistys (ELVIS ry., jäseniă 228 (1985)) ottaa jäsenekseen jokaisen tăllä alalla julkisesti toimivan kansalaisen, taidesäveltäjien yhdistys (Suomen Säveltäjät ry., jäseniä 78 (1985)) taas vain sellaisen säveltäjän, jonka "tuotanto yhdistyksen kokouksen mielestä on taiteellisesti arvokas". Edellinen on selvästi ammatillinen, jälkimmäinen taas aatteellinen yhdistys. Ehkă on kuitenkin korostettava, että siellä missä nämä valvovat etujaan (Teosto, Luovan Säveltaiteen Edistämissäätiö, Musiikin tiedotuskeskus) on asioista voitu sopia "fifty-fifty". Tosin tätä "linnarauhaa" on myös voitu pitäă näennäisenä - maan tunnetuimman viihdesäveltăjän, Toivo Kärjen sanoin:

... yleensä kevyen musiikin säeltäjät eivät pidä taidesäveltäjistä, jotka ovat olevinaan enemmän kuin ovat eivätkä taidemusiikin säveltäjät muutamaa poikkeusta lukuun ottamatta ... pidä kevyen musiikin säveltäjistä koska nämä syövät heille tarkoitettua leipää. (Niiniluoto 1982, 255).

\section{Kvalitatiivisia ja funktionaalisia eroja}

Taiteen ja viihteen kahtiajako löytyy kaikkialta länsimaista, joskin sosialistisissa maissa itse termit on kätketty. Esim. Neuvostoliitossa instrumentaalimusiikkia on kaikki sinfonioista torvisoittoon, vokaalimusiikkia taas kaikki oopperoista kansanlauluihin. Mutta sielläkin säveltäjät keskittyvät yleensä joko vakavaan tai kevyeeseen musiikkiin, joskin näiden välinen vuorovaikutus sekä tyylillinen liikkumavara on kokemusteni mukaan huomattavampi kuin meillä.

Olen etnomusikologien kanssa samaa mieltä siitä, että taide- ja populaarimusiikin kiistattomimmat erot ovat löydettävissä niiden historiasta, niiden 
kannattajien näkemyksistä sekä niiden yhteiskunnallis-taloudellisesta asemasta. Mutta näilläkin on reaaliset syynsä, joita seuraavassa yritän etsiä itse musiikin ominaisuuksista ja funktioista lähinnä tshekkiläisen musiikkisosiologin Vladimir Karbusickyn (1975) tutkimusten valossa.

Karbusickyn empiiriset tutkimukset osoittavat, että populaarimusiikissa vastaanottoprosessi on spontaanimpi ja asettaa kuulijalle pienemmät vaatimukset kuin taidemusiikissa. Musiikin vetoavuus joukkoihin (Massenhaftigkeit) laskee sitä mukaa, mită enemmän keskittynyttä, analyyttista kuulemista ja tradition tuntemusta se edellyttää ja mitä vähemmän se palvelee ulkomusiikillisia tarkoitusperiä ja hyötynäkökohtia. Tässä suhteessa hän katsoo taidemusiikin lähteneen omalle autonomiselle tielleen jo renessanssin aikana ja erkaantuneen "primaaris-kulttuurisesta" musiikista.

"Tarkoitusfunktioihinsa" (Zweckfunktion) sitoutuneena populaarimusiikin on oltava stereotyyppistä (Typenhaftigkeit). Tämä tulee esiin jo luomistapahtumassa, joka populaarimusiikissa on "fylogeneettinen", taidemusiikissa "ontogeneettinen". Edellinen edellyttää säveltäjältä olemassaolevien musiikkityyppien sellaista "uudistamista", ettei tuttuuden vaikutelma katoa, ts. pitäytymistä helposti tunnistettaviin lajipiirteisiin; jälkimmäinen taas tällaisten piirteiden nimenomaista kaihtamista. Se mikä populaarimusiikissa katsotaan tăsmällisyydeksi, ammattitaidoksi ja tarpeiden oikeaksi palvelemiseksi, merkitseekin taidemusiikissa taantumista ja epigonismia. Populaarimusiikissa "ikuiset arvot" ovat kappaleesta toiseen toistuvissa formeleissa, taidemusiikissa ne taas konkretisoituvat yksittäisissä, kauan elävissä ja siten musiikinhistoriallista tietoisuutta muokkaavissa teoksissa.

Näistä syistä populaarimusiikissa myös teos ja tekijä jäävät vähemmälle huomiolle kuin esitys ja esittäjä. Taidemusiikissa tilanne on päinvastainen, joskin Karbusicky joutuu myöntämään seikan, jota aiemmin tähdensin: kuluneimpien standarditeosten kohdalla kuulijan päähuomio kiintyy tulkintaan. Taiteellisuus merkitsee siis populaarimusiikissa esityksen taidokkuutta, taidemusiikissa taas itse musiikin struktuuriin sisältyvien "esteettisten arvojen summaa".

Siinä missä stereotyyppisyys on populaarimusiikille elinehto, merkitsee se taidemusiikille kuoliniskua. Kysymys ei ole vain siitä, muistuttavatko eri teokset toisiaan, vaan myös siitä, missä määrin teoksen sisäiset elementit muistuttavat toisiaan. Jatkuvan kertautumisen periaate, joka on populaari- ja kansanmusiikille tyypillinen, tulee taidemusiikissa kyseeseen vain poikkeustapauksissa, tiettyä tehoa tavoiteltaessa (esim. Stravinskyn Kevätuhri). Vaikka taidemusiikki suosii suurempia muotokokonaisuuksia kuin populaarimusiikki, niin olennainen ero ei piile teosten laajuudessa vaan niiden sisältämässä informaatiomäärässä. Informaatioteorian termein ilmaistuna populaarimusiikissa on huomattavasti enemmän redundanssia kuin taidemusiikissa.

Populaarimusiikki on etupäässä "naiivia" ja sille luontuu viihdyttävä funktio, kun taas taidemusiikki voi olla hyvinkin "filosofista" ja täyttää kognitiivisen funktion. Juuri tämä seikka on saanut ihmiset puhumaan "kevyestä" ja "vakavasta" musiikista. Karbusickyn ajatukset tukevat siis Ilkka Oramon näkymystä, jonka mukaan näiden termien vakiintuminen kieleen osoittaa, että ihmisillä keskimäärin on käsitys eri musiikkilajien tehtävistä (Oramo 1975, 64). 
Populaarikulttuurin kannattajien mukaan taas jako taiteeseen ja viihteeseen ei vastaa ihmisten tapaa kokea musiikkia (Lipponen 1983, 32). Oramon väitteellă on loogiset perusteensa, populaarimusiikin puolustajien väitettä taas olisi syytä koetella sosiologisin metodein.

Typologisesti ajatellen näyttäisi siltä, että populaarimusiikista kulkee jatkuva linja taidemusiikkiin sinfonisen jazzin, musikaalien, operettien yms. kautta. Mutta Karbusickyn mukaan raja ei olekaan helposti ylitettävissä vaan muodostaa laadullisen murroskohdan. Molemmille musiikinlajeille on osoitettavissa oma ominaisuutensa ja funktioista koostuva, kulttuurisidonnainen typologiansa. Miltei jokainen piirre, joka toisessa musiikkilajissa esiintyessään on positiivinen, onkin toisessa tulkittava negatiiviseksi. Kunkin sävelteoksen kohdalla joudutaan siis viime kädessä ratkaisemaan, minkä arvo-, normi- ja koodijärjestelmän mukaan sen adekvaatti vastaanotto tapahtuu. Näin ollen Karbusickyn johtopäätös kuuluu: taide- ja populaarimusiikki ovat "reaalisia entiteettejă", kahtiajako ei perustu mielivaltaiseen sosiaaliseen päätökseen eikä se poistaminen, "sovittaminen" ole mahdollista.

\section{Arvo-ongelma}

Lopuksi meidän on vielä palattava hankalimpaan kysymykseen: mitä voidaan sanoa taide- ja populaarimusiikin keskinäisestă arvosta? Ilkka Oramon mielestă taide on tietoisuutta avartavaa, viihde tietoisuutta supistavaa, mikä ei perustu näiden lajien funktioihin vaan ominaisuuksiin. Populaarimusiikki käyttää keinoja, jotka taidemusiikki on aikoinaan hylännyt niiden vakiinnuttua ja kadotettua tietoisuutta avartavan kykynsä (Oramo 1974, 336). Vastaavaan tapaan saksalaiset historioitsijat ovat selittäneet romantiikan "triviaalimusiikin" syntyă, kuten edellă ilmeni. Edellyttăisi kuitenkin hieman pitempäă pohtimista, miten hyvin tämä selitys sopii 1900-luvun historiallis-yhteiskunnalliseen todellisuuteen. Oràmon mielestă jokainen sinfonia "käyttăă yhteisiă aineksia rikkaammin ja monipuolisemmin, so. tiedostavammin ja oivaltavammin kuin yksikään iskelmä", joten on todennäköistä, että jokainen sinfonia on myös jokaista iskelmäă arvokkaampi (Oramo 1975, 64).

Pekka Gronow katsoo, että meikälăinen taidemusiikin estetiikka on oikeastaan vailla tieteenfilosofista pohjaa, "jonkinlaista tiedotonta saksalaisen idealismin jäännettä". Hän kirjoittaa:

Jos samaan aikaan hyväksyy länsimaisen intellektuaalin perinteen, on hyvin vaikea todistaa, että on olemassa objektiivisia perusteita osoittaa Joonas Kokkosen olevan parempi säveltäjä kuin Toivo Kärki. (Niiniluóto 1982, 295296).

Gronow on kuitenkin samaa mieltä Oramon kanssa siită, ettă musiikin arvo piilee sen informaatiossa ja kommunikaatiokyvyssä. Hän ei vain suostu vetämään jyrkkää arvorajaa taiteen ja viihteen välille (Gronow 1975, 61). Kiistan ydin 
näyttää olevan siinä, että Oramo văhättelee taiteen ja viihteen funktionaalisia, Gronow taas niiden kvalitatiivisia eroja.

Tällaiseen kiistaan ei Karbusicky ota suoranaisesti kantaa, mutta nähdäkseni hän ratkaisee sen niin pitkälle kuin musiikkitiede ylipäänsä voi. Jos hyväksymme hänen tapansa todentaa kahtiajako ja hänen tuloksensa, ts. jos hyväksymme, ettă sekä taiteella että viihteellä on kummallakin oma alueensa, oma tehtävänsä ja tämän mukaiset ominaispiirteet, ei jäljelle jää muita kuin eettisiä ja moraalisia kysymyksiä. Lattea johtopäätös on silloin seuraava: arvokkaampaa on se, jonka funktio yksilön ja yhteisön kannalta on tärkeämpi. - Tässä vaiheessa tekee mieli luopua leikistä. Mutta mitä se auttaa? Jonkun on kuitenkin tehtävă kulttuuripoliittisia päätöksiä jollakin perusteella. Joka tapauksessa näyttăä siltă, että demokratiamme kehityksessä olemme tulleet vaiheeseen, jossa taidemusiikin puolustajilta vaaditaan ei vain syvällisiă ja samalla riittăvăn kansantajuisia perusteluja vaan myös aimo annos siviilirohkeutta.

\section{Huomautus}

Kirjoitus on suomenkielinen versio Jyväskylässä elokuussa 1985 pidetyssä kolmannessa Alvar Aalto -symposiumissa, jonka teemana oli modernismi ja populaarikulttuuri - aihetta tarkastelivat elokuvan, kirjallisuuden ja musiikin edustajat.

\section{Lähteet}

Adorno, Theodor W.

1962 Einleitung in die Musiksoziologie. Frankfurt am Main.

1972 "Uber den Fetischcharakter in der Musik und die Regression des Hörens". Dissonanzen. 5. Auflage. Göttingen 1972.

Blacking, John

1981 "Making artistic popular music: the goal of true folk". Ed. by Richard Middleton and David Horn. Cambridge University Press.

Brooks, William

1982 "On being tasteless." Popular Music 2. Ed. by Richard Middleton and David Horn. Cambridge University Press.

Dahlhaus, Carl

1967a 'Vorwort." Studien zur Trivialmusik des 19. Jahrhunderts . Hrsg. von Carl Dahlhaus.

1967b "Trivialmusik und ästhetisches Urteil". Ks. 1967a.

Fabbri, Franco

1982 "What kind of music?". Ks. Brooks 1982.

Gronow, Pekka

1965 "Musiikkisosiologia ja musiikkipolitiikka". Sosiologia 1965:1.

1971 "Taide tutkimuksen kohteena". Sosiologia 1971:2.

1975 "Kuka tuntee musiikin todellisuuden?" Parnasso 1975:1

1983 "The record industry: the growth of a mass medium". Popular Music 3. Ed.

Heiniö, Mikko by Richard Middleton and David Horn. Cambridge University Press.

1984 Innovaation ja tradition idea. Näkökulma aikamme suomalaisten säveltäjien musiikkifilosofiaan. Helsinki. 
Hurri, Merja

1983 "Vero- ja raha-arpajaisvarojen käyttö musiikin edistämiseen". Suomen musiikin koko kuva. Suomen etnomusikologisen seuran julkaisu.

Karbusicky, Vladimir

1975 "Begriff und Ästhetik der 'leichten' und der 'emsten' Musik". Empirische Musiksoziologie. Wiesbaden.

Kokkonen, Pirjo

1983 'Viihdemusiikki suomalaisten taidesäveltäjien näkökulmasta 1960luvulla". Synkooppi op. 12.

Lipponen, Tapio

1983 Kemut eetterissä. Musiikin villitsijät vastaan vallitsijat. Jyväskylä.

Niiniluoto, Maarit

1982 Toivo Kärki. Siks oon mä suruinen. Helsinki.

Oramo, Ilkka

1974 "Musiikin todellisuus ja 'sosiologinen musiikinteoria"'. Parnasso 1974:6.

1975 "Sosiologiasta politiikkaan". Parnasso 1975:1.

Paddison, Max

1982 "The critique ciriticised: Adorno and popular music". Ks. Brooks 1982.

Pleasants, Henry

1955 The Agony of Modern Music. New York.

1969 Serious Music and All That Jazz. London.

Salmenhaara, Erkki (Ed.)

1976 Miten sävellykseni ovat syntyneet. Keuruu.

Saunio, Ilpo

1982 "Mitä on etnomusikologia?". Äänenkannattaja 1982:2.

Shepherd, John

1982 "A theoretical model for the sociomusicological analysis of popular

Tagg, Philip musics". Ks. Brooks 1982.

1982 "Analysing popular music: theory, method and practice". Ks. Brooks 1982.

\section{Summary}

\section{Art music and popular music}

Over the last decades there has been a vivid discussion about the status of art music and popular music in Finnish society. Reports show that financial support from the state is mainly directed towards performers and composers of art music; similarly, music education puts an emphasis on art music; and the state-supported radio broadcasting company favours classical music: it broadcasts yearly 4,000 hours of art music and 6,000 hours of light music - in spite of the fact that the former programmes are listened to by about 7 percent and the latter 93 percent of radio listeners. At the same time, the production of commercial records is strongly based on popular music: 85 percent of the total output is light music.

Thus, in Finland, the decision makers seem to believe on one hand that art music is in a decisive position when one aims at cultivating and developing our cultural heritage and educating people, on the other hand that commercial popular music can survive without their help.

The advocates of art music emphasize the cognitive, aesthetic, and educational function of music. This function is strictly bound to the value of music. 
Composers of modern music (Neue Musik) often follow the philosophy of Schoenberg and Adorno's Wahrhaftigkeit, according to which a composition has to strive for truth, i.e. it should critically reflect the reality of its moment of birth - otherwise it is false escapism. Thus, the triviality of music is defined not only aesthetically-compositionally but morally as well.

Ethnomusicologists for their part have emphasized the relative and social nature of artistic values. They say that the value of music is defined by man and by society, and this value is different in various cultural contexts. Most ethnomusicologists seem to be irritated by the established division into art and entertainment, which ignores certain intermediary musical forms and suggests that popular music in its entirety would be an inseparable part of a brainwashing mass culture, and "a conspiracy against man".

The art-entertainment dichotomy in music has often been supported by the Adornoan view according to which the listener to entertainment music is passively oriented and overwhelmed by a false consciousness. This music takes on the characteristics of a fetish and a commodity. Art music, on the contrary, is not a merchandise. Thus, art music and popular music are not conmensurable because the valuable and the worthless are not comparable.

Ethnomusicologists seem to be correct in claiming that the most indisputable differences are to be found in their history, in the views of their advocates, and in their social status. However, the reasons for this division, as V. Karbusicky has pointed out, derive from the qualities of music and its different functions. "The eternal values" of popular music lie in the patterns that repeat themselves from one song to another. In art music, on the other hand, they are manifested in longlasting individual works that form the musico-historical consciuosness. Where stereotypical patterns are a prerequisite for popular music, it is a deathblow to art music. Both genres can be shown to have a culture-bound typology of their own; both are real entities, and their dichotomy is not based on an arbitrary social decision that can be valid at one time and not at another. If we accept this Karbusickian view nothing but ethical and moral issues remain. But whether one of these genres is more valuable than the others is not a question for musicologists to solve. 